\title{
The hydrothermal solubility of beryllium oxide in $\mathrm{NaOH}$ solutions
}

\author{
By \\ Isamu SHINDO* and Hiroshige SUZUKI** \\ (* National Institute for Researches in Inorganic Materials
** Tokyo Institute of Technology
}

\section{Introduction}

Beryllium oxide has recentry attracted special attention as a ceramic material because it has a very high melting point, lower specific gravity, higher electrical resistance, particularly at elevated temperature, and a much greater thermal conductivity.

Good quality single crystals of reasonable size have been grown by $f_{u x^{1) ~ 3)}}$ and hydrothermal methods ${ }^{4}$ which enable the growth of more perfect and strain free crystals than are generally obtained using high temperature method.

On the hydrothermal method are reported only a few papers. Newkirk and Smith ${ }^{5}$ have determined the solution reactions for $\mathrm{BeO}-\mathrm{H}_{2} \mathrm{O}$ and $\mathrm{BeO}-\mathrm{NaOH}-\mathrm{H}_{2} \mathrm{O}$ systems with varied concentrations of $\mathrm{NaOH}$ as a function of temperature and pressure up to $600^{\circ} \mathrm{C}$ and 4500 bars where $\mathrm{Be}(\mathrm{OH})_{2}$ is used as a starting material. Newkirk ${ }^{2}$ has also determined the hydrothermal solubility of $\mathrm{BeO}$ in $\mathrm{NaOH}$ solution. Hill and Harker" have measured the solubility of $\mathrm{BeO}$ in $\mathrm{NaOH}$ solutions between 4.0 and $8.0 \mathrm{~mol}$ at temperature 400 and $800^{\circ} \mathrm{C}$ for pressure ketween 15000 and 60000 psi and grown single crystal of $\mathrm{BeO}$ on the plate like seed crystal under hydrothermal conditions. Unfortunately, their solubility data are very conflicting, and thermodynamic data of solution reactions are not determined. The solubility data will aid in elucidating the mechanism of hydrothermal crystal growth in general and will suggest more suitable conditions for crystal growth.

E.U. Franck ${ }^{6)}$ has discussed the solubility of solid substances under hydrothermal conditions. Franck has also derived expressions predicting the dependence of solubility on the specific volume of the solvent from a concideration of the thermodynamics of a constant volume system. R.A. Laudise and A.A. Ballman ${ }^{7)}$ determined the hydrothermal solubility of quartz expressed as $\mathrm{g} / 100 \mathrm{cc}$ free volume of the reaction chamber of the autoclave.

Recently, the hydrothermal solubility has been measured by noble metal can method, which avoids the hydrothermal corrosion and needs not so many samples. For example, the solubility of $\mathrm{Al}_{2} \mathrm{O}_{3}$ in $\mathrm{NaOH}$ solution ${ }^{8)}$ and the solubility of $\mathrm{LiGaO}_{2}$ in $\mathrm{NaOH}$ solution ${ }^{9}$.

If the hydrothermal solubility is to be expressed in terms of $\mathrm{g} / \mathrm{specific}$ volume, it is necessary for this to determine the $P-V-T$ relation under hydrothermal conditions. G.C. Kennedy has measured the $P-V-T$ relations for pure water under hydrothermal conditions, but for other solvents such as $\mathrm{NaOH}$ solutions, none of experiment have been made of $P-V-T$ relations under the same conditions up to the present.

D.J. Marshall ${ }^{9}$ ) calculated the density of $\mathrm{NaOH}$ solutions by assuming that the $P-V-T$ data for a $0.50 \mathrm{~mol} \mathrm{NaOH}$ solution was the same as that for pure water. But it is evident that this assumption did not apply to more concentrated solutions in which the $P-V-T$ relations differ from pure water. Under these conditions, it is not possible to express the hydrothermal solubility as $\mathrm{g} /$ free volume. The solubility was therefore defined as $\mathrm{g} / 100 \mathrm{~g}$ solvent or $\mathrm{mol} / 1000 \mathrm{~m} l$ solution at room temperature. According to this definition, the solubility has significance on all the hydrothermal experiments.

\section{Experimental}

Hydrothermal solubility has generally been determined by the weight loss method. In this method, the most important cause of error is the recrystallization on the solid piece during the quench. Another cause of error is that the degeneration occurs and brings any new solid phase.

Fortunately, $\mathrm{BeO}$ is known to be the stable phase under the experimental conditions, then the solubility data are reliable provided that the recrystallization does not occur. To avoid this trouble, the sudden explosion and the quench methods are used at the same time. The procedure, which will be stated later, was essentially the same as that used by Barns et al. ${ }^{8)}$ in their 
study of the solubility of corundum in basic hydrothermal solvent.

One end of the gold tube (typically $0.5 \mathrm{~mm}$ o.d. $\times 40 \mathrm{~mm}$ long and $0.2 \mathrm{~mm}$ wall thickness and capacity is $0.5 \mathrm{ml}$ ) was crimed and welded. Small prism-like single crystals of $\mathrm{BeO}$ (Lithium molybdate flux grown, about $20 \mathrm{mg}$ in weight) were sealed into a gold capsule with the required amount of $\mathrm{NaOH}$ solutions. The capsule was placed into the autoclave. The autoclave used was Tuttle cold seal type test tube which had 0.25 inch i.d. and 8 inch long and capacity was $7.3 \mathrm{ml}$. The electric furnace was a nichrome wound ceramic tube long enough to avoid end effects. The autoclave was attached to a pump and a pressure gauge. Water was pumped into the autoclave up to desired pressure and heated up to desired temperature about $1 \mathrm{hr}$ and held at least 2 days at that conditions. There were good agreement between duplicated run for two days and those run for longer time.

It indicates that equilibrium was attained within two days. The autoclave was then rapidly quenched with pressed air and cold water.

Just at the same time, inert pressure became zero by treating the leak cock. The capsule was then opened and the $\mathrm{BeO}$ source crystal was washed, dried and weighted.

In all cases where a solubility was determined, the crystal surface showed no evidence of recrystallization during the quench.

From the weight loss and known weight of solution in the capsule the solubility could be calculated. All $\mathrm{NaOH}$ concentration are expressed in terms of molality, which are standardized against $0.1 \mathrm{~mol} \mathrm{HCl}$ solution with bromophenol blue as indicator.

\section{Results}

The solubility of $\mathrm{BeO}$ was measured in 3.9, $5.5,8.7$ and 13.1 molal $\mathrm{NaOH}$ solutions at pressures of 500, 1000 and 1500 bar.

The results obtained are shown in Fig. 1 and 2. Each point represents the average of two or three separate determinations for each set of conditions. Duplicates were considered acceptable if they did not differ their mean value by more than $\pm 2.5 \mathrm{wt} \%$ and over half of all duplicate runs ray within $2.0 \mathrm{wt} \%$ of their mean.

In most cases, the experimental results showed slight curvature, but in the case of the solubility at 1500 bar in $8.7 \mathrm{~mol} \mathrm{NaOH}$ solution the straight line was drawn through the experimental points.

The solubility has strongly depended on molality up to $13.1 \mathrm{~mol} \mathrm{NaOH}$ solutions. However the solubility in $0.5 \sim 13.1 \mathrm{~mol} \mathrm{NaOH}$ solution in the temperature range of $250 \sim 600^{\circ} \mathrm{C}$ is apparently

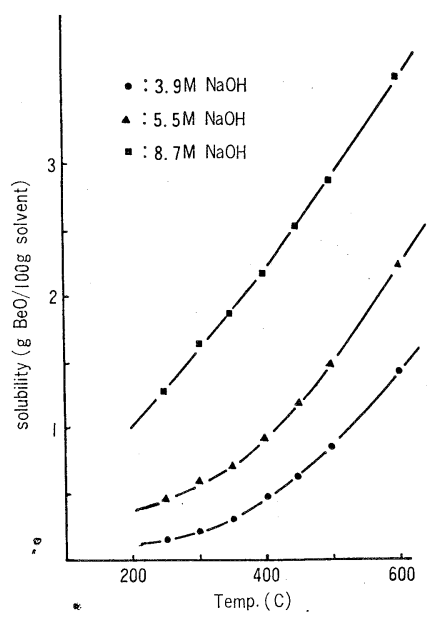

Fig. 1. Solubility of $\mathrm{BeO}$ as a function of temperature at 1500 bars.

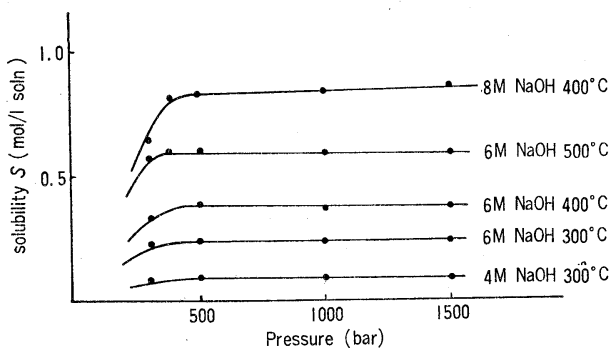

Fig. 2. Solubility of $\mathrm{BeO}$ as a function of pressure.

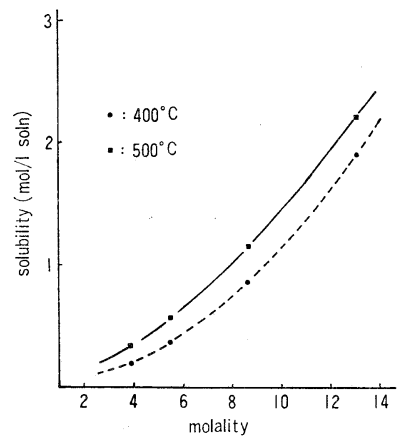

Fig. 3. Solubility of $\mathrm{BeO}$ as a function of $\mathrm{NaOH}$ concentration at 1500 bars.

independent of pressure for those from 500 to 1500 bars. Similar characteristics have been reported in the case of the solubility of $\mathrm{Al}_{2} \mathrm{O}_{3}$ in $\mathrm{NaOH}$ solution.

These phenomena are shown in Fig. 3.

\section{Discussion}

According to Franck ${ }^{6}$, the solution of quartz in pure water can be represented by the following relation.

$$
\mathrm{SiO}_{2}+n \mathrm{H}_{2} \mathrm{O}=\mathrm{SiO}_{2} \cdot n \mathrm{H}_{2} \mathrm{O}
$$

Equation (1) assumes no ionization of the silicon 
hydroxide formed.

In basic solution, Laudise et al. ${ }^{7)}$ have assumed that the generalized reaction describing the interaction of quartz with $(\mathrm{OH})^{-}$in aqueous solution would be

$$
\begin{aligned}
& \mathrm{SiO}_{2}+(2 a-4)(\mathrm{OH})^{-} \\
& \quad=\mathrm{SiO}_{a}{ }^{(2 a-4)-}+(a-2) \mathrm{H}_{2} \mathrm{O}
\end{aligned}
$$

Equation (2) assumes a complete ionization of sodium silicate formed. Then the dissolution of quartz in aqueous $\mathrm{NaOH}$ solutions obviously involve the equation (1) and (2). However since the loss of weight of quartz will not allow the separate determination of the concentration of $\mathrm{SiO}_{2} \cdot n \mathrm{H}_{2} \mathrm{O}$ and $\mathrm{SiO}_{a}^{(2 a-4)-}$, Laudise et al. have proposed the following equation as the dissolution of quartz.

$$
\begin{aligned}
& 2 \mathrm{SiO}_{2}+n \mathrm{H}_{2} \mathrm{O}+(2 a-4)(\mathrm{OH})^{-} \\
& \quad=\mathrm{SiO}_{2} \cdot n \mathrm{H}_{2} \mathrm{O}+\mathrm{SiO}_{a}^{(2 a-4)}-+(a-2) \mathrm{H}_{2} \mathrm{O}
\end{aligned}
$$

In $\mathrm{BeO}-\mathrm{NaOH}-\mathrm{H}_{2} \mathrm{O}$ system, the solubility of $\mathrm{BeO}$ in pure water is less than $0.02 \mathrm{wt} \%$ at 600 ${ }^{\circ} \mathrm{C}$ and 1500 bars, this term is negligible for the qualitative determination of the dissolution of $\mathrm{BeO}$.

Then it is suggested that the equation describing the dissolution of $\mathrm{BeO}$ in $\mathrm{NaOH}$ solution is similar to that suggested for $\mathrm{SiO}_{2}$;

$$
\begin{aligned}
& \mathrm{BeO}+2(m-1)(\mathrm{OH})^{-}=\mathrm{BeO}_{m}{ }^{2(m-1)-} \\
& \quad+(m-1) \mathrm{H}_{2} \mathrm{O}(m>1) \ldots \ldots \ldots \ldots \ldots \ldots \ldots
\end{aligned}
$$

The equilibrium constant $K_{i}$ for the equation (4) can be written

$$
K_{i}=\frac{r_{\mathrm{BeO}_{m}^{2}(m-1)-} \cdot C_{\mathrm{BeO}_{m}^{2}(m-1)-}}{\left[r_{\mathrm{OH}}-C_{\mathrm{OH}}-\right]^{2(m-1)}}
$$

where $\gamma_{i}$ and $C_{i}$ are the activity coefficient and the molality of the species concerned respectively. These expressions can be combined with that for the dissociation of the $\mathrm{NaOH}$

$$
K_{\mathrm{NaOH}}=\frac{\left[r_{\mathrm{Na}^{+}} \cdot C_{\mathrm{Na}^{+}}\right]\left[\mathrm{rOH}^{-} \cdot C_{\mathrm{OH}^{-}}\right]}{r_{\mathrm{NaOH}} \cdot C_{\mathrm{NaOH}}} \cdots(6)
$$

to yield a relationship between the solubility and the concentration of $\mathrm{NaOH}$. From the dependence of the equilibrium constant upon temperature, it is often possible to estimate the enthalpy of solution provided that the Clausius-Clapeyron equation is obeyed;

$$
\log K_{i}=-\frac{\Delta H}{4.576 T}+C
$$

It must then be assumed that $\Delta H$ is not a function of temperature and the activities of all the components are all constant under hydrothermal conditions for the calculation of the $\Delta H$ value.

Among all $\log K_{i}-1 / T$ relations, the linear relation were only observed when $m=2, m=2.5$.

Put the number $m=2.5$ to the equation (4), it becomes as follows.

$$
\mathrm{BeO}+3(\mathrm{OH})^{-}=\mathrm{BeO}_{2.5}{ }^{3-}+1.5 \mathrm{H}_{2} \mathrm{O} \cdots \cdots(8)
$$

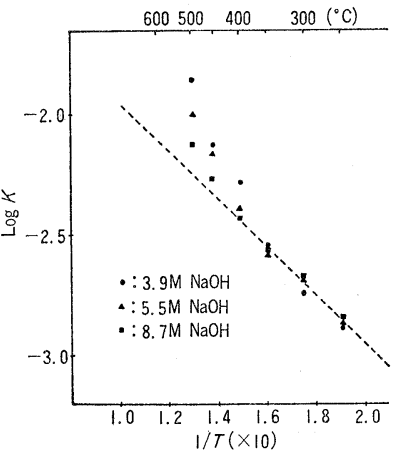

Fig. 4. $\log K$ vs. $1 / T$ at several molalities. $\mathrm{BeO}+3(\mathrm{OH})^{-}=\mathrm{BeO}_{2}(\mathrm{OH})^{3-}+\mathrm{H}_{2} \mathrm{O}$

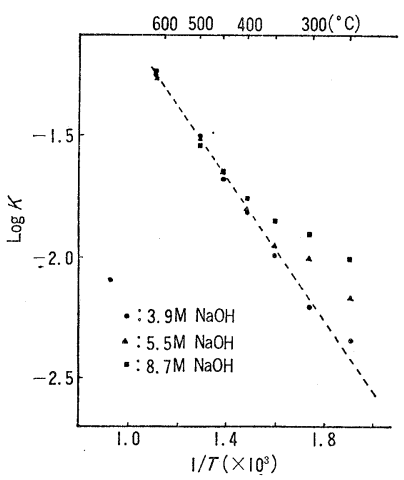

Fig. 5. $\log K$ vs. $1 / T$ at several molalities. $\mathrm{BeO}+2(\mathrm{OH})^{-}=\mathrm{BeO}_{2}{ }^{2-}+\mathrm{H}_{2} \mathrm{O}$

On the contrary, if hydroxyl ion is present, the following equation should be satisfied :

$\mathrm{BeO}+3(\mathrm{OH})^{-}=\mathrm{BeO}_{2}(\mathrm{OH})^{3-}+\mathrm{H}_{2} \mathrm{O} \cdots(9)$

but it is considered that the species of $\mathrm{BeO}_{2.5^{3-}}$ has few possibilities, therefore, the species of $\mathrm{BeO}(\mathrm{OH})^{3-}$ is considered to be reasonable one. From the Fig. 4 which shows the relation of $\log$ $K$ vs. $1 / T$ when $m=2.5$, the linear relation is observed below about $350^{\circ} \mathrm{C}$.

From the Fig. 5 which is the case of $m=2$, the linear relation is observed higher than about $400^{\circ} \mathrm{C}$. The equation (4) makes as follows.

$$
\mathrm{BeO}+2(\mathrm{OH})^{-}=\mathrm{BeO}_{2}{ }^{2-}+\mathrm{H}_{2} \mathrm{O}
$$

From each $\log K_{i}$ to $1 / T$ relations, $\Delta H$ can be calculated as follows.

$$
\begin{aligned}
\Delta H_{1} & =4.6 \pm 0.1 \mathrm{kcal} / \mathrm{mol} \\
\quad\left(\text { equation }(9), \text { below } 350^{\circ} \mathrm{C}\right) & \\
\Delta H_{2}=7.1 \pm 0.1 \mathrm{kcal} / \mathrm{mol} & \left.\quad \text { (equation }(10), \text { above } 400^{\circ} \mathrm{C}\right)
\end{aligned}
$$

It is deduced that the dissolution reaction of $\mathrm{BeO}$ in $\mathrm{NaOH}$ solution varies with temperature and molality. From the Fig. 4 and 5, the dissolution reaction of $\mathrm{BeO}$ in $\mathrm{NaOH}$ solutions is varied from the equation (9) to the equation (10) at about $400^{\circ} \mathrm{C}$. This transition temperature is increased as the consentration of $\mathrm{NaOH}$ solutions 
are increased.

The heat of solution is generally calculated from the dependence of the solubility upon temperature provided that the Van't Hoff equation is obeyed.

$$
\log S=-\frac{\Delta H}{4.576 T}+C
$$

The Van't Hoff equation needs the assumption that the composition of solvent is not changed and that the dissolving species does not change in all experimental conditions. In practice however the composition of solvent is changed as the dissolution proceeds.

In case of the dissolution of $\mathrm{BeO}$ in $\mathrm{NaOH}$ solutions, the logarithmic solubility of $\mathrm{BeO}$ is plotted against the reciprocal of the absolute temperature as shown in Fig. 6. Two straight line are observed which have the same slope. From the slope of the each straight line in Fig. 6 , the values of the heat of solution of $\mathrm{BeO}$ in $\mathrm{NaOH}$ solution are calculated as follows.

$$
\Delta H_{3}=2.7 \pm 0.1 \mathrm{kcal} / \mathrm{mol} \text { (A region) }
$$$$
\Delta H_{4}=5.0 \pm 0.1 \mathrm{kcal} / \mathrm{mol} \text { (B region) }
$$

If the Van't Hoff equation is obeyed, the heat of solution is expected to be constant at all experimental conditions, these results mean that the different dissolution reaction must be occurred under the experimental conditions.

The solubility of $\mathrm{BeO}$ is almost independent of pressure, which means that the solubility is independent of the density. Such property is quite contrary to the result found for quartz but is similar to the dissolution of $\mathrm{Al}_{2} \mathrm{O}_{3}$ in $\mathrm{NaOH}$ solutions ${ }^{8)}$.

Several reasons have been advanced for the lack of solubility dependence on pressure by Barnes et al. ${ }^{8}$ in their study of the solubility of $\mathrm{Al}_{2} \mathrm{O}_{3}$ in $\mathrm{NaOH}$ solution. For example the density change is very little in comparison with a similar pressure range for quartz. However, those reasons seem unlikely.

In $\mathrm{BeO}-\mathrm{NaOH}-\mathrm{H}_{2} \mathrm{O}$ system, the dissolution reaction changes from the equation (9) to the equation (10) at about $400^{\circ} \mathrm{C}$, which corresponds nearly to the three phase resion (solid-liquidgas). It is considered that the dissolving species are different in this system.

Namely below $350^{\circ} \mathrm{C}$, the main reaction is expressed in the equation (9) which exist in liquid

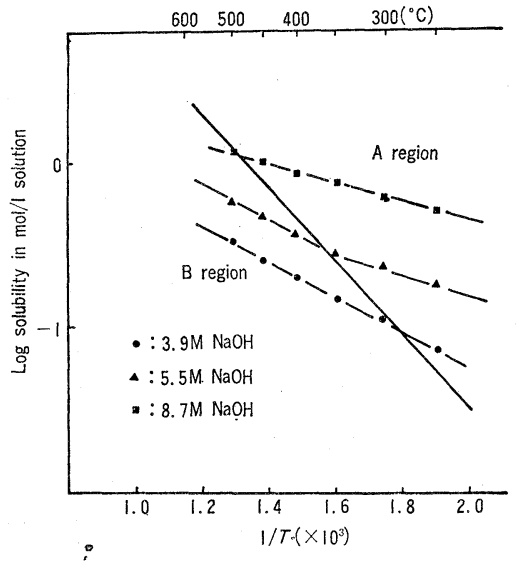

Fig. 6. $\log S$ vs. $1 / T$ at several moralities.

phase. And above $400^{\circ} \mathrm{C}$, the main reaction is expressed as the equation (10) which exists in gas phase.

This transition temperature is varied with the concentration of basic solution. This phenomenon is interpreted as the critical point varied with the concentration of basic solution.

\section{Acknowledgements}

The authors wish to acknowledge the assistance of Dr. H. Kojima, Y. Kuniya, and Y. Hasegawa in preparing the source crystals, and Dr. H. Einaga for chemical analysis of the solutions.

\section{References}

1) J.W. Kelly, Intr. Conf. On Beryllium Oxide. Sydney, Paper 56, Oct. (1963).

2) H.W. Newkirk, D.K. Smith, Am. Mineral. 50, 44, (1965).

3) S.B. Austerman, J. Nucl. Materials. 14, 225 (1964).

4) V.G. Hill, R.I. Harker, J. Electrochem. Soc. 115, 294 (1968).

5) H.W. Newkirk, D.K. Smith, Am. Mineral. 50, 22 (1965).

6) E.U. Franck, Z. Physik. Chem. (Frankfurt) 8, 345 (1956).

7) R.A. Luudise, A.A. Ballman, J. Am. Chem. Soc. 80, 2655 (1958).

8) R.L. Barnes, R.A. Laudise, R.M. Shields, J. Phys. Chem. 67, 835 (1963).

9) D.J. Marshall, R.A. Laudise, J. Crystal Growth, 1, 88-92 (1967).

10) G.C. Kennedy, Am. J. Sci. 248, 560 (1950).

[Receivd May 30, 1974] 


\section{酸化ベリリウムの $\mathrm{NaOH}$ 溶液中における水熱溶解度}

\section{進藤勇・鈴木弘茂}

（科学技術庁 無機材質研究所, 東京工業大学 原子炉工学研究所）

酸化ベリリウムの $\mathrm{NaOH}$ 溶液中における水熱溶解度 を測定し，その溶解機構を明らかにすると共に，溶解 の活性化エネルギーを算出した. 酸化ベリリウムの $\mathrm{NaOH}$ 溶液中への溶解反応は単一ではなく, 約 $350^{\circ} \mathrm{C}$ 付近より低温側では次の (1) 式に, $400^{\circ} \mathrm{C}$ 付近以上では (2) 式に従っているものと推論された.

(1) $\mathrm{BeO}+3(\mathrm{OH})^{-}=\mathrm{BeO}_{2}(\mathrm{OH})^{3-}+\mathrm{H}_{2} \mathrm{O}$

(2) $\mathrm{BeO}+2(\mathrm{OH})^{-}=\mathrm{BeO}_{2}{ }^{2-}+\mathrm{H}_{2} \mathrm{O}$
(1) 式から（2）式への転移温度は, $\mathrm{NaOH}$ 溶液の濃 度が高くなるにつれて, 高温側にずれて行く.

一方, これら 2 つの溶解反応に対して, それぞれ Van't Hoff の式が成立し, これから溶解の活性化エネ ルギーは (1) 式に対しては $2.7 \pm 0.1 \mathrm{kcal} / \mathrm{mol},(2)$ 式 に対しては $5.0 \pm 0.1 \mathrm{kcal} / \mathrm{mol}$ と計算された.

(5/30/1974 受付) 